\title{
Treated Coal Bottom Ash for Palm Oil Mill Effluent (POME) Decolourisation
}

\author{
Syahin Saleh, ${ }^{1}$ Wan Azlina Wan Ab Karim Ghani ${ }^{1 *}$ and Soh Kheang Loh $^{2}$ \\ ${ }^{1}$ Department of Chemical and Environmental Engineering/Process \\ Engineering Research Centre (SPERC), Faculty of Engineering, \\ Universiti Putra Malaysia, 43400 UPM Serdang, Selangor, Malaysia \\ ${ }^{2}$ Energy and Environment Unit, Engineering and Processing Research Division, \\ Malaysian Palm Oil Board, Bandar Baru Bangi, \\ 43000 Kajang, Selangor, Malaysia \\ *Corresponding author: wanazlina@upm.edu.my
}

Published online: 25 November 2019

To cite this article: Saleh, S., Ghani, W. A. W. A. K. \& Soh, K. L. (2019). Treated coal bottom ash for palm oil mill effluent (POME) decolourisation. J. Phys. Sci., 30(3), 101-116, https://doi.org/10.21315/jps2019.30.3.7

To link to this article: https://doi.org/10.21315/jps2019.30.3.7

\begin{abstract}
The coal bottom ash (CBA) sourced from thermal power plant was chemically treated using hydrochloric acid ( $\mathrm{HCl}$ ), namely $\mathrm{CBA}-\mathrm{HCl}$, and used as an adsorbent for palm oil mill effluent (POME) decolourisation. The treated CBA-HCl was characterised for surface property via Brunauer-Emmett-Teller (BET), surface chemistry via Fourier transform infrared (FTIR) and surface morphology via scanning electron microscopy (SEM). Its effectiveness for adsorption of POME colour was investigated via batch experiments as a function of $\mathrm{pH}$, initial POME concentration, adsorbent dosage and contact time. The adsorption increased with increasing contact time until an equilibrium state was achieved within $18 \mathrm{~h}$ to $24 \mathrm{~h}$. The maximum POME colour removal, 81.15\% was achieved at pH 6 utilising 14\% (w/v) adsorbent dosage for $24 \mathrm{~h}$. The colour adsorption isotherm and kinetics of the CBA-HCl was well-fitted with Freundlich and pseudo-second order models with correlation coefficient, $R^{2}=0.9991$ and $R^{2}=0.9996$, respectively. Based on the results, CBA can be a potential adsorbent in removing POME colour before being discharged into a watercourse.
\end{abstract}

Keywords: Palm oil, wastewater, colour, removal, adsorption, bottom ash 


\section{INTRODUCTION}

Palm oil is one of the major agro-industries in Malaysia covering millions of hectares of cultivated area. It has contributed substantially to economic growth and an improved living standard. Along the supply chain in the midstream sector where palm oil is extracted, a considerable amount of palm oil mill effluent (POME) is generated in mills. ${ }^{1}$ While about 40 million tonnes of POME was reported in 2004, the figure increased to 60 million tonnes in 2009, i.e., an almost $50 \%$ increase of POME volume in 5 years. ${ }^{2,3}$ Generally, POME is treated in a series of ponding system which involves low capital and operating cost. ${ }^{4}$ Being polluting naturally due to high organic strength, it is also highly coloured causing photosynthesis activities reduction, and the polluted water endangers aquatic life. ${ }^{5}$ The colour is derived from plant constituents such as tannin, lignin, humic and fulvic acid like substances, phenolic compounds as well as re-polymerisation of the colouring compound. ${ }^{6}$ To date, the colour of POME has attracted considerable attention due to its "stubborn" characteristic and appearance as a critical water quality parameter. It affects mostly the environment which is essential to tourism. Several biological, physical and chemical methods have been proposed for POME decolourisation including membrane technology, filtration, biodegradation, oxidation, coagulation and photocatalysis..$^{7-12}$ However, many of these technologies are costly especially when applied for large scale treatment. Adsorption method, on the other hand, appears to be the most potential in wastewater treatment as it is low cost, simple and effective. ${ }^{13,14}$

Activated carbon has been identified as an effective adsorbent for removal of a wide variety of organic and inorganic pollutants from aqueous or gaseous media. ${ }^{15}$ However, its application is still limited due to high cost and difficulty in regeneration. ${ }^{16}$ This situation has driven researchers to look for low-cost adsorbent in replacing activated carbon. Several studies have revealed some low-cost adsorbents for colour removal of POME such as natural clay, palm kernel shell, fly ash and empty fruit bunch. ${ }^{17-20}$

Coal bottom ash (CBA) is a waste material generated abundantly from combustion of solid fuels. Its disposal at surrounding land is undesirable, and of concern since this kind of dumping is wasteful and considered highly unsuitable for agricultural utilisation. ${ }^{21}$ The CBA appears as granules of dark grey black colour and it releases relatively less heavy metals than its fly ash counterpart. ${ }^{22,23}$ It is also a highly porous material suitable for pollutant adsorption process. ${ }^{24}$ It has potential for POME decolourisation based on its colour removal potential reported in the literature, owning to its good adsorption capacity by the present trace elements such as silicone and aluminium..$^{25-29}$ 
This study aimed at investigating the effectiveness of CBA derived from thermal power plant for POME decolourisation. The initial POME concentration, contact time, $\mathrm{pH}$ and chemically-treated CBA dosage on colour removal of POME were examined. The respective colour adsorption kinetics and isotherms were also studied.

\section{EXPERIMENTAL}

\subsection{CBA Preparation}

CBA was obtained from a local coal-fired power plant in Manjung, Perak, Malaysia. The CBA obtained was a sand-like material, non-combustible and in dark grey granular form. It was soaked in distilled water (DW) at CBA:DW ratio of 1.0:1.5 for $48 \mathrm{~h}$ without stirring in order to remove any impurities present. The CBA was then filtered and dried in an oven at $70^{\circ} \mathrm{C}$ for 2 days. Next, it was ground by mortar until fairly fine and sieved to obtain CBA of equal size of $500 \mu \mathrm{m}$. Then, $50 \mathrm{~g}$ of CBA was stirred with $500 \mathrm{ml}$ of $0.1 \mathrm{~N} \mathrm{HCl}$ for $24 \mathrm{~h}$ in a beaker using magnetic stirrer. ${ }^{30}$ The solution was left overnight to allow full sedimentation of CBA at the bottom of the beaker. The treated CBA, namely CBA-HCl was washed with an excess of DW until $\mathrm{pH}$ neutral. Lastly, the adsorbent was filtered and dried in an oven at $70^{\circ} \mathrm{C}$ for 2 days, and kept in a container prior to use.

\subsection{Collection of POME}

POME was collected from POME discharging pipe at a palm oil mill in Maran, Pahang, Malaysia and stored in a chiller at $4^{\circ} \mathrm{C}$ prior to analysis and experiment. The final POME discharge had a colour concentration of 1099 PtCo unit. It was alkaline at $\mathrm{pH} 8.4$.

\subsection{Adsorption Study}

Adsorption experiments were performed in batches at room temperature using an orbital shaker at $160 \mathrm{rpm}$ for the following operating conditions: (a) $\mathrm{pH}$, 6, 7, 8 and 9; (b) initial POME concentrations $20 \%, 40 \%, 60 \%, 80 \%$ and $100 \%$; (c) adsorbent dosages $1.8 \mathrm{~g}, 2.4 \mathrm{~g}, 3.0 \mathrm{~g}, 3.6 \mathrm{~g}$ and $4.2 \mathrm{~g}$; and (d) contact times $0.5 \mathrm{~h}$, 1 h, 1.5 h, 2 h, 3 h, 4 h, 6 h, 10 h, 12 h, 18 h and 24 h. For pH operating conditions, five $30 \mathrm{ml}$ POME samples were prepared, and their $\mathrm{pH}$ adjusted using $0.1 \mathrm{~N} \mathrm{HCl}$ or $0.1 \mathrm{~N} \mathrm{NaOH}$ to the desired $\mathrm{pH}$ values. Next, $4.2 \mathrm{~g}$ of CBA-HCl was added to each sample and shaken for $24 \mathrm{~h}$. The POME samples were diluted with DW to the desired concentrations. The raw POME sample representing original concentration 
without dilution was denoted by $100 \%$. The $\mathrm{pH}$ of all samples was adjusted to $\mathrm{pH}$ 6. Similarly, $30 \mathrm{ml}$ of each POME sample was mixed with $4.2 \mathrm{~g} \mathrm{CBA}-\mathrm{HCl}$ and agitated for $24 \mathrm{~h}$. For adsorbent dosage, the desired CBA-HCl dosages of $1.8 \mathrm{~g}$, $2.4 \mathrm{~g}, 3.0 \mathrm{~g}, 3.6 \mathrm{~g}$ and $4.2 \mathrm{~g}$ were added in $30 \mathrm{ml}$ of each POME sample at $\mathrm{pH}$ 6 in a $250 \mathrm{ml}$ Erlenmeyer flask. The samples were shaken at $160 \mathrm{rpm}$ for $24 \mathrm{~h}$. For contact time, the same experiment was repeated for different contact times using $4.2 \mathrm{~g} \mathrm{CBA}-\mathrm{HCl}$ at $\mathrm{pH}$ 6. Prior to colour analysis using spectrophotometer, all samples were filtered to prevent interference from adsorbent fines.

\subsection{Analyses}

The colour of POME was analysed using HACH spectrophotometer DR2700 at wavelength $455 \mathrm{~nm}$ according to platinum-cobalt standard method 8025 . Scanning electron microscopy or SEM (Hitachi, S-3400N) was used to observe the morphology of $\mathrm{CBA}-\mathrm{HCl}$, and its functional groups were determined using Fourier transform infrared (FTIR) spectroscopy (Perkin Elmer Spectro 100 series USA) in the $600-4000 \mathrm{~cm}^{-1}$ region. Specific surface area was determined based on Brunauer-Emmett-Teller (BET) gas adsorption method using BET-Autosorb-1C (AXIS-MP-LP, Quantachrome instrument).

\section{RESULTS AND DISCUSSION}

\subsection{CBA Characterisation}

Figure 1 shows surface methodology of CBA-HCl analysed using SEM. Generally, porosity of an adsorbent has specific impact on colour adsorption. Based on the SEM images, the acid-treated CBA had highly porous structure with many small and large pores. The $\mathrm{CBA}-\mathrm{HCl}$ possessed macroporous structure with pore size ranges starting from $10 \mu \mathrm{m}$ as shown in Figure 1(b). The adsorbent surface was shiny, clean, rough and free of dust. Based on the porous structure shown, it was concluded that $\mathrm{HCl}$ treatment had managed to increase the surface area and charges of CBA which would have positive influence during colour adsorption of POME. 

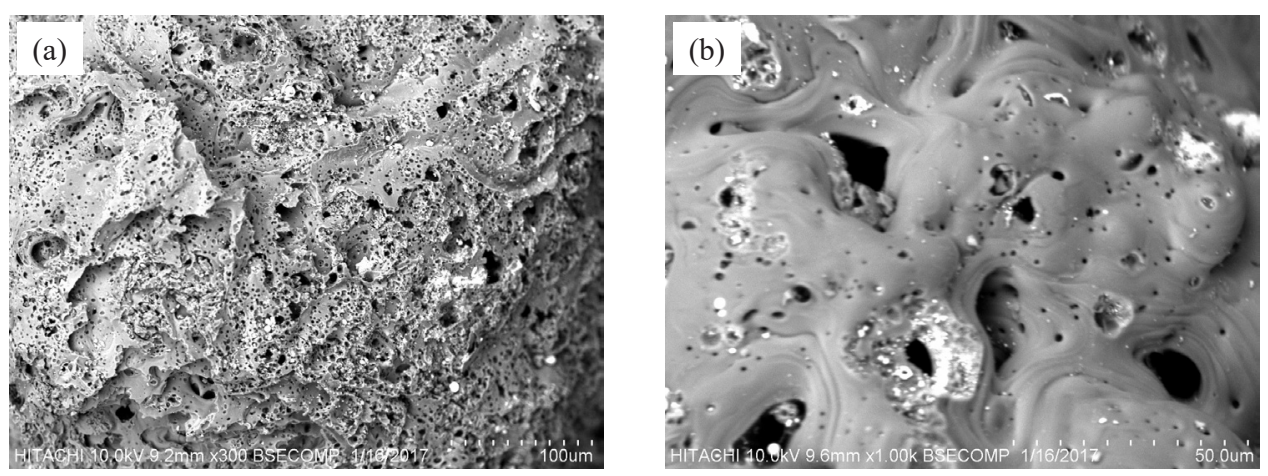

Figure 1: Surface morphology of $\mathrm{CBA}-\mathrm{HCl}$ at (a) 300X magnification, and (b) 1000X magnification.

\subsubsection{BET surface area analysis}

The BET surface analysis was conducted to study the characteristics of the sample pores. Based on Tables 1 and 2, the untreated CBA had higher surface area $\left(6.80 \mathrm{~m}^{2} \mathrm{~g}^{-1}\right)$ compared with other untreated CBA obtained elsewhere. The CBA$\mathrm{HCl}$ in this study exhibited a 6-fold surface area increment, i.e., $44.15 \mathrm{~m}^{2} \mathrm{~g}^{-1}$ after acid treatment, which was indicative of a good activation employed. The higher the surface area of $\mathrm{CBA}-\mathrm{HCl}$, the more surface areas are available for adsorption; thus providing greater adsorptive capacity during POME colour adsorption. ${ }^{31,32}$

Table 1: BET analysis for untreated and treated CBA in this study.

\begin{tabular}{lccc}
\hline Sample & BET surface area $\left(\mathrm{m}^{2} \mathrm{~g}^{-1}\right)$ & Pore volume $\left(\mathrm{cm}^{3} \mathrm{~g}^{-1}\right)$ & Pore width $(\AA)$ \\
\hline Untreated CBA & 6.80 & 0.1151 & 677.09 \\
CBA-HCl & 44.15 & 0.1535 & 139.02 \\
\hline
\end{tabular}

Table 2: Specific surface area of bottom ash from various sources.

\begin{tabular}{lccc}
\hline Sample & BET surface area $\left(\mathrm{m}^{2} \mathrm{~g}^{-1}\right)$ & Source & Reference \\
\hline Untreated CBA & 6.80 & Manjung, Perak & Present study \\
CBA-HCl & 44.15 & Manjung, Perak & Present study \\
Untreated CBA & 1.04 & Kapar, Selangor & Present study \\
Untreated CBA & $0.17-1.00$ & NA & Jayaranjan et al. ${ }^{33}$ \\
Untreated CBA & 1.25 & Shanxi, China & Sun et al. ${ }^{34}$ \\
Untreated CBA & 1.77 & Corlu, Turkish & Dincer et al. ${ }^{23}$ \\
\hline
\end{tabular}

Notes: NA denotes no information available 


\subsubsection{FTIR analysis}

The various functional groups present on the surface of the CBA-HCl were identified by FTIR spectroscopy (Figure 2). It was found that CBA had a strong presence at $3746 \mathrm{~cm}^{-1}$ which was characteristic of a non-acidic $\mathrm{Si}-\mathrm{OH}$ group. Its presence was originated from -OH of water molecules associated with silicarich extra-framework debris. ${ }^{35,36}$ Broad band at around $3501 \mathrm{~cm}^{-1}$ was assigned to hydroxyl $(-\mathrm{OH})$ groups and amine groups. ${ }^{37}$ The $\mathrm{O}-\mathrm{H}$ stretching vibrations occurring within a broad band indicated presence of "free" -OH groups as well as bonded O-H groups of carboxylic acids. ${ }^{38}$ Meanwhile, the bands at $787 \mathrm{~cm}^{-1}$ represented $\mathrm{SiO}-\mathrm{H}$ vibration. ${ }^{39}$ The FTIR spectrum showed the presence of many polar functional, i.e., carboxyl, carbonyl, hydroxyl and amino groups which were responsible and involved in colour binding during POME treatment using CBA$\mathrm{HCl}^{38}$

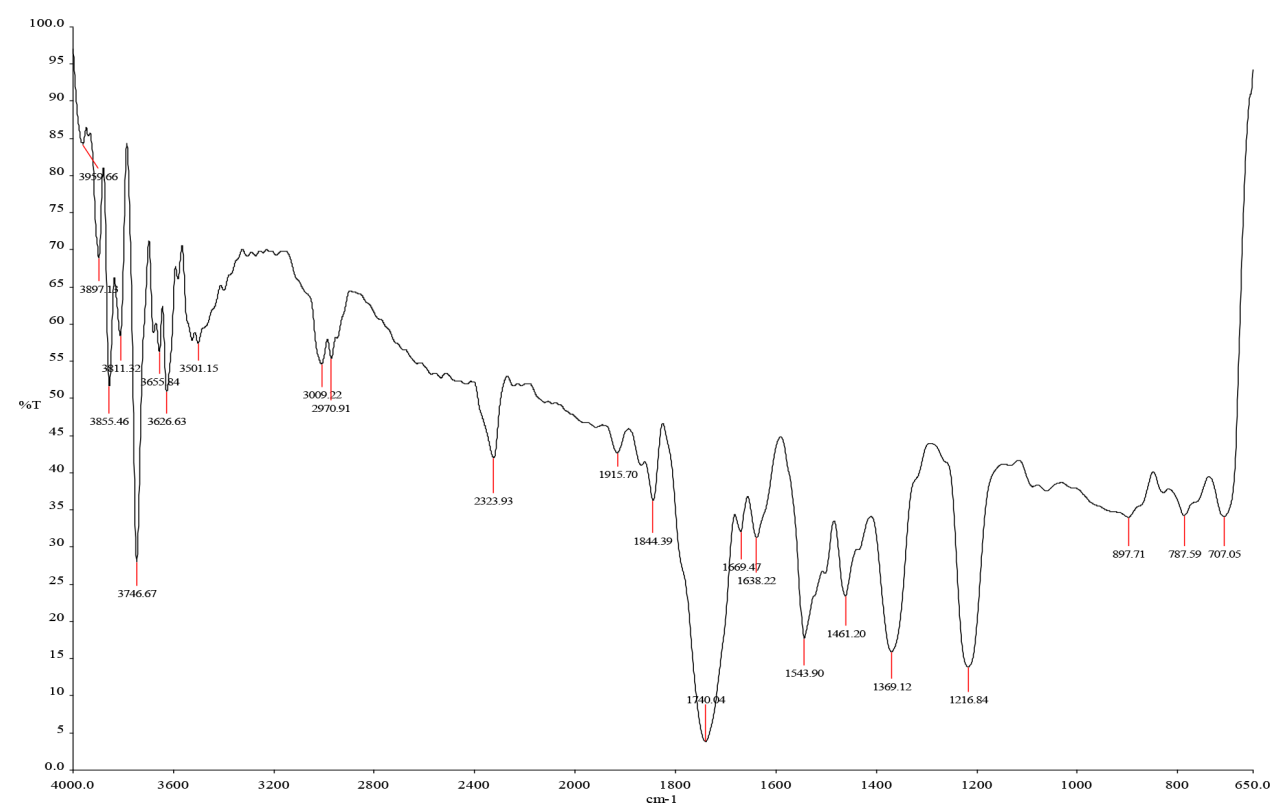

Figure 2: FTIR spectrum of CBA-HCl. 


\subsection{Adsorption Analysis}

\subsection{1 pH of POME}

Figure 3 shows the effect of $\mathrm{pH}$ on percentage removal of colour from POME. The $\mathrm{pH}$ of a solution plays a vital role in adsorption process as it influences the sensitivity of functional groups of adsorbate. ${ }^{20}$ According to Mohammed, changes in solution $\mathrm{pH}$ affect adsorbent surface load and influence the degree of colour compounds attraction. ${ }^{20}$ In this study, $\mathrm{pH} 6$ gave the highest percentage of colour removal, i.e., $81.15 \%$ among the $\mathrm{pH}$ used as a result of higher degree of protonation of the active sites on CBA- $\mathrm{HCl}$ surface. At this $\mathrm{pH}$, the surface of adsorbent was positively charged and this facilitated sorption of anioinic functional groups of coloured compounds which led to better POME colour removal. ${ }^{20} \mathrm{As} \mathrm{pH}$ increased or decreased, positively charged sites reduced, hence lower POME colour removal as shown by lower adsorption efficiency of CBA-HCl, i.e., $77.92 \%, 73.16 \%$, $71.97 \%$ and $70.18 \%$, at $\mathrm{pH} 5,7,8$ and 9 , respectively. The findings indicated that $\mathrm{pH}$ indeed had a significant effect on the performance of CBA-HCl for POME decolourisation.

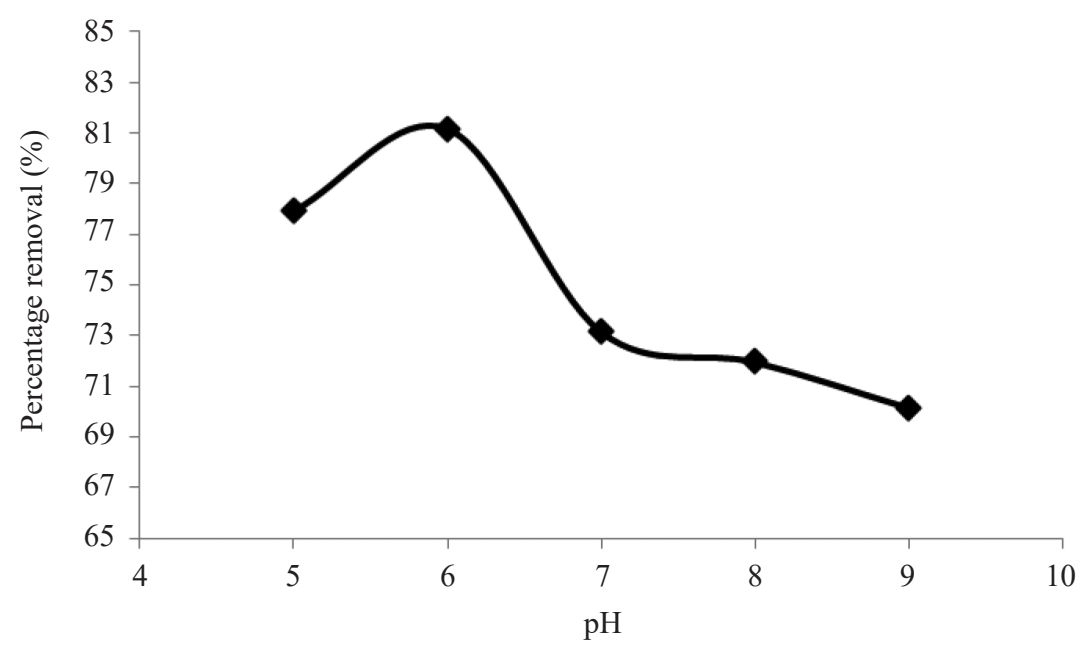

Figure 3: Effect of $\mathrm{pH}$ on percentage colour removal of POME.

\subsubsection{Adsorbent dosage}

The CBA-HCl dosage was varied from $6 \%$ to $14 \%(\mathrm{~m} / \mathrm{v})$. Figure 4 shows the effect of adsorbent dosage on percentage removal of POME colour. The percentage of POME colour removal increased with increasing of CBA-HCl dosage. Adsorption rate depends on driving power per unit area. ${ }^{20}$ As dosage of adsorbent increased, 
more surface area would be provided to adsorb colour from POME. In Figure 4, colour removal from POME was most efficient at the highest CBA-HCl dosage of $14 \%(\mathrm{w} / \mathrm{v})$ due to the highest number of available adsorption sites. The higher the adsorbent dosage, the higher the availability of adsorption sites which can enhance the performance of colour removal. However, the percentage of removal does not increase proportionately with the adsorbent dose. Although significant colour removal was observed at lower dosage but beyond $10 \%(\mathrm{~m} / \mathrm{v})$, the increase had only gone up slightly by about $3 \%$.

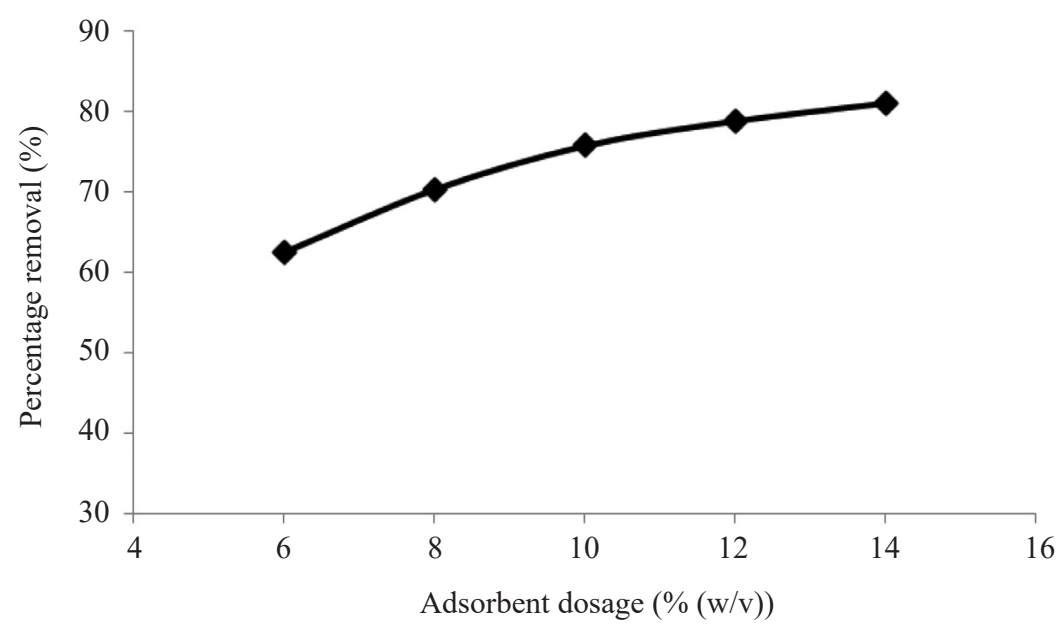

Figure 4: Effect of adsorbent dosage on percentage colour removal of POME.

\subsubsection{Contact time}

The effect of contact time was studied to determine the sorption rate of POME colour onto $\mathrm{CBA}-\mathrm{HCl}$ and its associated equilibrium time. Figure 5 shows that the adsorption of POME colour reached equilibrium within $24 \mathrm{~h}$. Concentration of POME colour decreased drastically in the first $3 \mathrm{~h}$ and remained constant from $18 \mathrm{~h}$ to $24 \mathrm{~h}$. The optimum contact time was found at $18 \mathrm{~h}$ for adsorption of POME colour. The adsorption rate was rapid initially due to greater availability of actives sites on $\mathrm{CBA}-\mathrm{HCl}$ surface. As time passed, more and more active sites got occupied by coloured molecules resulting in much saturated surface and lesser available sites to be offered for adsorption. This phenomenon created a repulsive force between the coloured molecules in medium and on $\mathrm{CBA}-\mathrm{HCl}$ surface, hence the percentage colour removal of POME gradually slowed down. ${ }^{40}$ 


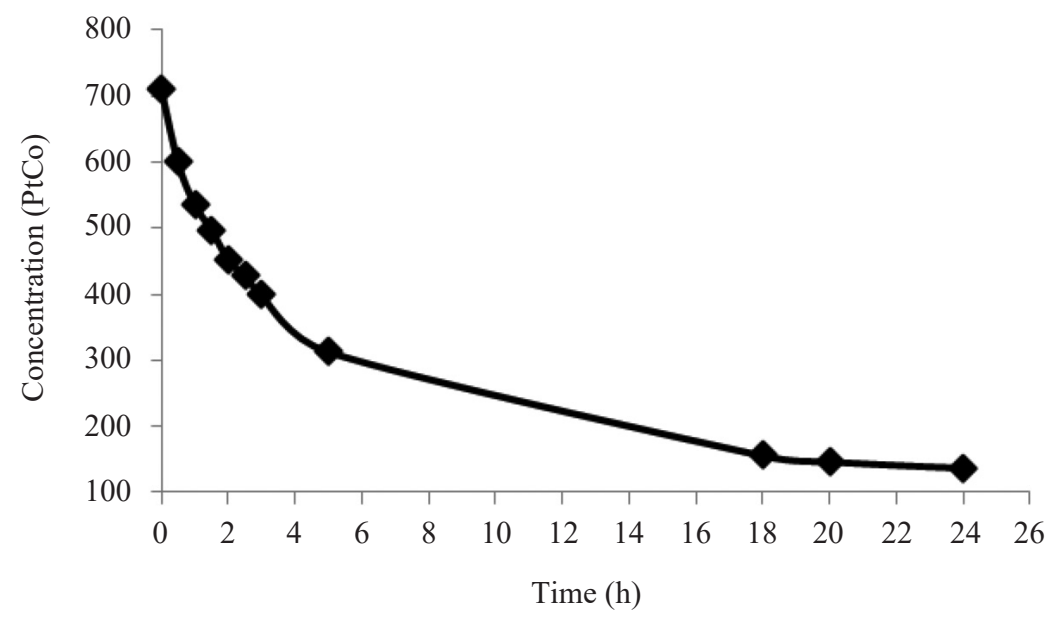

Figure 5: Effect of contact time on colour removal of POME.

\subsubsection{Adsorption capacity}

Adsorption capability of CBA- $\mathrm{HCl}$ on POME colour was shown in Figure 6. The adsorption capacity $\left(\mathrm{q}_{\mathrm{e}}\right)$ increases linearly with increasing final concentration of POME. The maximum $\mathrm{q}_{\mathrm{e}}$ of CBA-HCl was recorded at $5.70 \mathrm{PtCo} / \mathrm{g}$. This $\mathrm{q}_{\mathrm{e}}$ was way lower than those of other adsorbents as presented in Table 3. Some precipitates had formed after the adsorption experiment probably due to chemical reaction between trace elements present in $\mathrm{CBA}-\mathrm{HCl}$ and some reactive POME components.

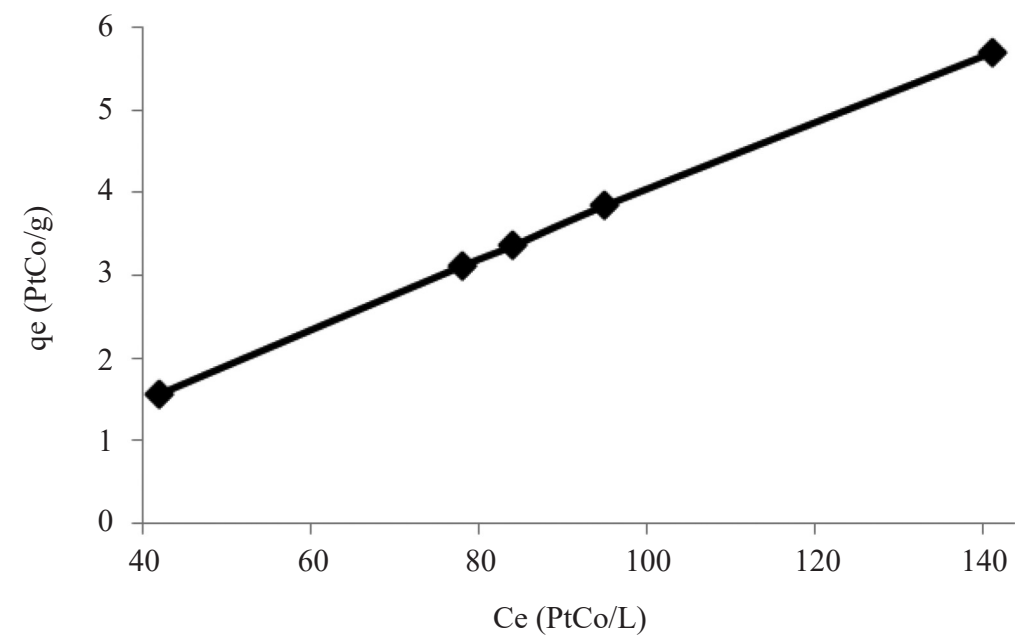

Figure 6: Equilibrium adsorption of POME colour at various initial concentration. 
Table 3: Comparison of adsorption capacity $\left(\mathrm{q}_{\mathrm{e}}\right)$ of CBA-HCl with other studies.

\begin{tabular}{lcc}
\hline Adsorbents & $\mathrm{q}_{\mathrm{e}}(\mathrm{PtCo} / \mathrm{g})$ & References \\
\hline CBA-HCl & 5.70 & Present study \\
Coconut shell activated carbon (CSAC) & 39.10 & Sia et al. ${ }^{41}$ \\
Palm kernel shell activated carbon & 227.27 & Jalani et al. $^{18}$ \\
Montmorillonite & 1.00 & Said et al. $^{17}$ \\
Microwave activated palm kernel shell (PKSM) & 191.00 & Mohammed $^{20}$ \\
Microwave activated empty fruit bunch (EFBM) & 186.50 & \\
\hline
\end{tabular}

\subsection{Adsorption Isotherm}

It is important to establish the most appropriate correlation for the equilibrium curves in order to optimise the design of an adsorption system for adsorption of colour from POME. Langmuir and Freundlich models were used to describe the equilibrium characteristics of POME colour adsorption. The Freundlich equations deployed as in Equation 1 was linearised as shown in Equation 2. As for Langmuir, the linearised equation is given by Equation 3 .

$$
\begin{aligned}
& q_{e}=k_{f} C_{e}{ }^{1 / n} \\
& \log q_{e}=1 / n \log C_{\mathrm{e}}+\log k_{f} \\
& C_{e} / q_{e}=1 / q_{\mathrm{m}} C_{\mathrm{e}}+1 /\left(k_{L} q_{\mathrm{m}}\right)
\end{aligned}
$$

In the equations, $q_{e}$ is the amount of pollutant adsorbed per gram of adsorbent at equilibrium ( $\left.\mathrm{mg} \mathrm{g}^{-1}\right), C_{e}$ was the equilibrium concentration of pollutant in the solution $\left(\mathrm{mg} \mathrm{l}^{-1}\right)$, and $k_{f}$ and $n$ are the constants for Freundlich to indicate the $q_{e}$ and intensity, respectively. These constant values can be obtained from the slope and intercept of the plot of $\log q_{e}$ versus $\log C_{e}$ while $q_{\mathrm{m}}$ and $k_{L}$ are the Langmuir constants that can be obtained from the slope and intercept from the plots of $C_{e} / q_{e}$ versus $C_{e}$. The $q_{\mathrm{m}}$ value is the maximum pollutant uptake capacity for the respective adsorbent and conditions. In this case, unit of $C_{e}$ is expressed as $\mathrm{PtCo} / \mathrm{L}$.

The best-fitted POME colour adsorption onto CBA-HCl with Freundlich isotherm $\left(\mathrm{R}^{2}=0.9991\right)$ reveals a heterogenous surface binding mechanism for adsorption of colour onto CBA-HCl compared to the less fitted Langmuir isotherm $\left(\mathrm{R}^{2}=0.6194\right)$ as shown in Figure 7. Meanwhile, Table 4 lists the respective constant values used. 
(a)

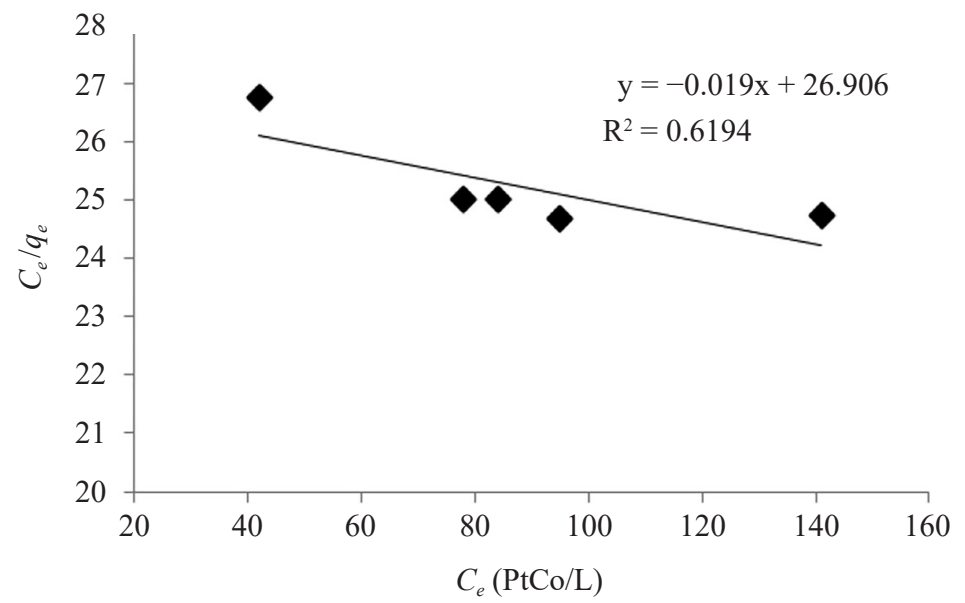

(b)

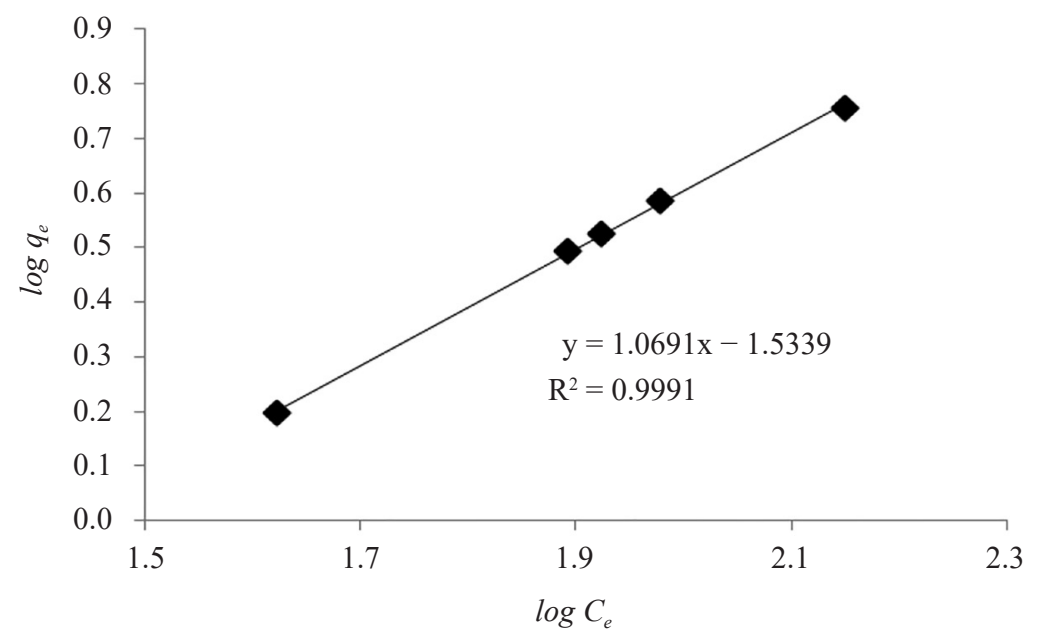

Figure 7: Isotherm model of (a) Langmuir, and (b) Freundlich for POME colour adsorption by $\mathrm{CBA}-\mathrm{HCl}$, respectively.

Table 4: Adsorption isotherms parameters.

\begin{tabular}{lcccccccc}
\hline & \multicolumn{3}{c}{ Langmuir isotherm } & & \multicolumn{3}{c}{ Freundlich isotherm } \\
\cline { 1 - 3 } \cline { 7 - 9 } Parameter & $\mathrm{q}_{\max }\left(\mathrm{mg} \mathrm{g}^{-1}\right)$ & $\mathrm{K}_{\mathrm{L}}$ & $\mathrm{R}^{2}$ & & $\mathrm{~K}_{\mathrm{F}}$ & $\mathrm{n}$ & $\mathrm{R}^{2}$ \\
\hline Colour & -52.6316 & 0.00071 & 0.6194 & & 0.0292 & 0.9354 & 0.9991 \\
\hline
\end{tabular}




\subsection{Adsorption Kinetics}

The experimental adsorbate uptake rates onto $\mathrm{CBA}-\mathrm{HCl}$ was investigated using kinetic models. The adsorption kinetic based on the overall adsorption rate of CBA-HCl was analysed by pseudo-first order and pseudo-second order models as shown in Figure 8. The $\mathrm{R}^{2}$ value of pseudo-second order, shown in Figure 8(b), was higher compared with $\mathrm{R}^{2}$ value of pseudo-first order, as in Figure 8(a). Thus, the pseudo-second order model was most suitable to describe the adsorption kinetic involved. The findings showed that the step controlling adsorption rate of $\mathrm{CBA}-\mathrm{HCl}$ was chemical sorption and POME colour adsorption rate was affected by the number of available adsorption sites on the surface of $\mathrm{CBA}-\mathrm{HCl}$ rather than POME solution concentration. ${ }^{41,42}$ Table 5 shows the respective $q_{e}, K_{l}$ of first order adsorption, and $K_{2}$ of pseudo second order adsorption.
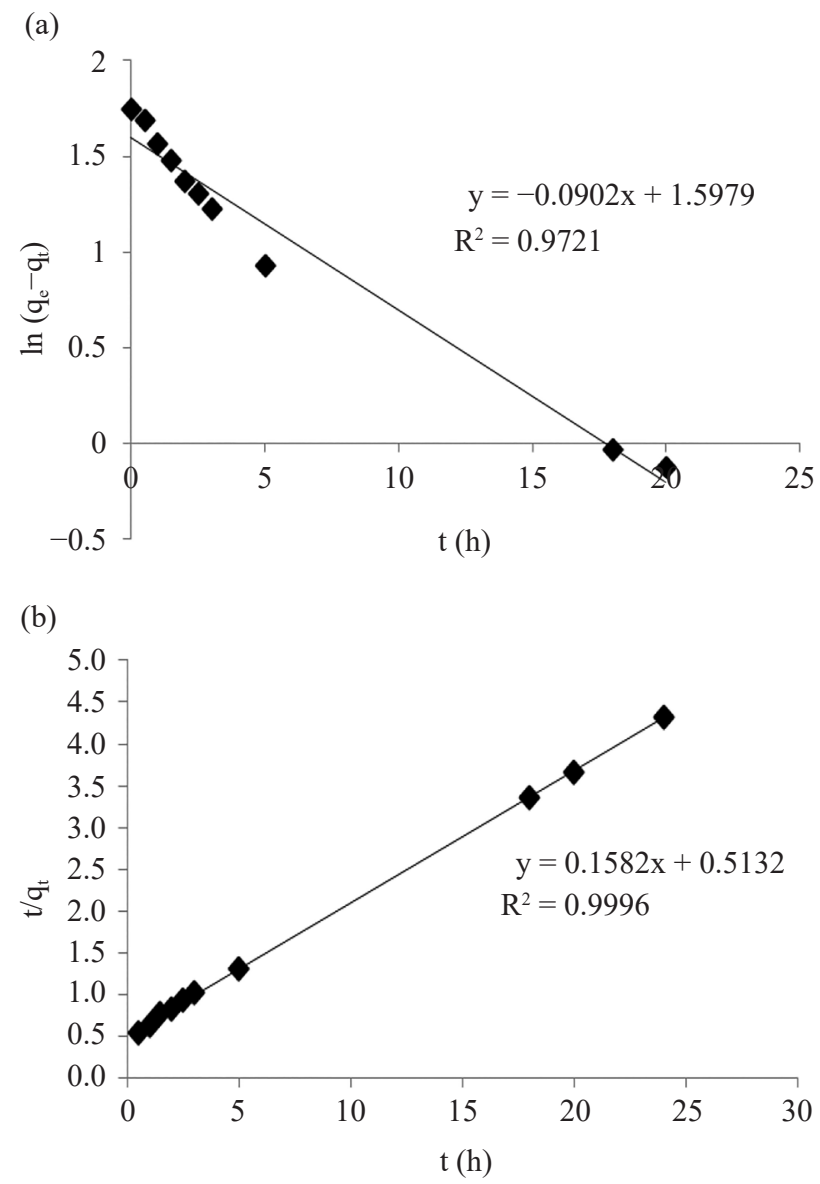

Figure 8: Kinetic model of (a) pseudo-first order, and (b) pseudo-second order for POME colour adsorption by $\mathrm{CBA}-\mathrm{HCl}$, respectively. 
Table 5: Adsorption kinetic parameters.

\begin{tabular}{lcccccccc}
\hline & \multicolumn{3}{c}{ Pseudo-first order } & & \multicolumn{3}{c}{ Pseudo-second order } \\
\cline { 1 - 3 } \cline { 6 - 8 } Parameter & $q_{e}\left(\mathrm{mg} \mathrm{g}^{-1}\right)$ & $K_{l}\left(1 \mathrm{~h}^{-1}\right)$ & $\mathrm{R}^{2}$ & & $q_{e}\left(\mathrm{mg} \mathrm{g}^{-1}\right)$ & $K_{2}\left(\mathrm{~g} \mathrm{mg}^{-1} \mathrm{~h}^{-1}\right)$ & $\mathrm{R}^{2}$ \\
\hline Colour & 4.9426 & 0.0902 & 0.9721 & & 6.3211 & 0.0488 & 0.9996 \\
\hline
\end{tabular}

\section{CONCLUSION}

A by-product of thermal power plant, namely CBA, had ability to remove coloured compounds of POME. The treated $\mathrm{CBA}-\mathrm{HCl}$ had developed more pores and bigger surface area after acid treatment. This material performed well in colour removal of POME, hence showing potential for colour adsorption during POME treatment. The optimum contact time, $\mathrm{CBA}-\mathrm{HCl}$ dosage and $\mathrm{pH}$ for POME colour removal were $18 \mathrm{~h}, 10 \%(\mathrm{w} / \mathrm{v})$ and $\mathrm{pH}$ 6, respectively. It was found that Freundlich and pseudo-second order models were best fitted for POME colour adsorption. The acid-treated CBA can be an alternative adsorbent in wastewater treatment.

\section{ACKNOWLEDGEMENTS}

The authors gratefully acknowledge the financial support from the Newton Fund and the EPSRC/RCUK (grant number: EP/PO18165/1) for partial funding of this research.

\section{REFERENCES}

1. Ratpukdi, T. (2012). Decolorization of anaerobically treated palm oil mill wastewater using combined coagulation and vacuum ultraviolet-hydrogen peroxide. Int. J. Chem. Eng. Appl., 3(5), 333-336, https://doi.org/10.7763/IJCEA.2012. V3.212.

2. Limkhuansuwan, V. \& Chaiprasert, P. (2010). Decolorization of molasses melanoidins and palm oil mill effluent phenolic compounds by fermentative lactic acid bacteria. J. Environ. Sci., 22(8), 1209-1217, https://doi.org/10.1016/S10010742(09)60240-0.

3. Ng, F. Y. et al. (2011). A renewable future driven with Malaysian palm oil-based green technology. J. Oil Palm Res., 2, 1-7.

4. $\mathrm{Wu}, \mathrm{T}$. Y. et al. (2010). Pollution control technologies for the treatment of palm oil mill effluent (POME) through end-of-pipe processes. J. Environ. Manage., 91(7), 1467-1490, https://doi.org/10.1016/j.jenvman.2010.02.008. 
5. Neoh, C. H. et al. (2013). Optimization of decolourization of palm oil mill effluent (POME) by growing cultures of Aspergillus fumigatus using response surface methodology. Environ. Sci. Pollut. Res., 20, 2912-2923, https://doi.org/10.1007/ s11356-012-1193-5.

6. Zahrim, A. Y., Nasimah, A. \& Hilal, N. (2014). Pollutants analysis during conventional palm oil mill effluent (POME) ponding system and decolourisation of anaerobically treated POME via calcium lactate-polyacrylamide. J. Water Process Eng., 4, 159-165, https://doi.org/10.1016/j.jwpe.2014.09.005.

7. Amat, N. A. A. et al. (2015). Tackling colour issue of anaerobically-treated palm oil mill effluent using membrane technology. J. Water Process Eng., 8, 221-226, https://doi.org/10.1016/j.jwpe.2015.10.010.

8. Subramaniam, M. N. et al. (2017). Hydrophilic hollow fiber PVDF ultrafiltration membrane incorporated with titanate nanotubes for decolourization of aerobicallytreated palm oil mill effluent. Chem. Eng. J., 316, 101-110, https://doi.org/10.1016/j. cej.2017.01.088.

9. Elmi, H. S. A., Nor, M. H. M. \& Ibrahim, Z. (2015). Colour and COD removal from palm oil mill effluent (POME) using Pseudomonas aeruginosa strain NCIM 5223 in microbial fuel cell. Int. J. Waste Manage., 5(3), 1-3, https://doi. org/10.4172/2252-5211.1000181.

10. Bashir, M. J. K. et al. (2017). Electro persulphate oxidation for polishing of biologically treated palm oil mill effluent (POME). J. Environ. Manage., 193, 458-469, https://doi.org/10.1016/j.jenvman.2017.02.031.

11. Sontaya, K., Pitiyont, B. \& Punsuvon, V. (2013). Decolorization and COD removal of palm oil mill wastewater by electrocoagulation. J. Environ. Chem. Eco. Geo. Geophy. Eng. Int., 7(9), 606-609.

12. Tan, Y. H. et al. (2014). Treatment of aerobic treated palm oil mill effluent (AT-POME) by using $\mathrm{TiO}_{2}$ photocatalytic process. Jurn. Teknol., 70(2), 61-63, https://doi.org/10.11113/jt.v70.3436.

13. Hasan, M., Ahmad, A. L. \& Hameed, B. H. (2008). Adsorption of reactive dye onto cross-linked chitosan/oil palm ash composite beads. Chem. Eng. J., 136, 164-172, doi:https://doi.org/10.1016/j.cej.2007.03.038.

14. Ali, I., Asim, M. \& Khan, T. A. (2012). Low cost adsorbents for the removal of organic pollutants from wastewater. J. Environ. Manage., 113, 170-183, https://doi.org/10.1016/j.jenvman.2012.08.028.

15. Tascon, J. M. D. (2012). Novel carbon adsorbent. Madrid: Elsevier.

16. Vimonses, V. et al. (2009). Kinetic study and equilibrium isotherm analysis of Congo red adsorption by clay materials. Chem. Eng. J., 148, 354-364, https://doi. org/10.1016/j.cej.2008.09.009.

17. Said, M. et al. (2016). Removal of COD, TSS and colour from palm oil mill effluent (POME) using montmorillonite. Desalin. Water Treat., 57, 10490-10497, https://doi.org/10.1080/19443994.2015.1036778.

18. Jalani, N. F. et al. (2016). Application of palm kernel shell activated carbon for the removal of pollutant and color in palm oil mill effluent treatment. J. Earth Environ. Health Sci., 2(1), 15-20, https://doi.org/10.4103/24237752.181802 . 
19. Igwe, J. C., Onyegrado, C. O. \& Abia, A. A. (2010). Adsorption isotherm studies of BOD, TSS and colour reduction from palm mill effluent (POME) using boiler fly ash. Ecl. Quím., 35(3), 195-208.

20. Mohammed, R. R. (2013). Decolourisation of biologically treated palm oil mill effluent (POME) using adsorption technique. Int. Ref. J. Eng. Sci., 2(10), 1-11.

21. Gupta, V. K. et al. (2004). Adsorption kinetics and column operations for the removal and recovery of malachite green from wastewater using bottom ash. Sep. Purif. Technol., 40(1), 87-96, https://doi.org/10.1016/j.seppur.2004.01.008.

22. Mittal, A. et al. (2008). Process development for the batch and bulk removal and recovery of a hazardous, water-soluble azo dye (metanil yellow) by adsorption over waste materials (bottom ash and de-oiled soya). J. Hazard. Mater., 151(2), 821-832, https://doi.org/10.1016/j.jhazmat.2007.06.059.

23. Dincer, A. R., Gunes, Y. \& Karakaya, N. (2007). Coal-based bottom ash (CBBA) waste material as adsorbent for removal of textiles dyestuffs from aqueous solution. J. Hazard. Mater., 141, 529-535, https://doi.org/10.1016/j.jhazmat.2006.07.064.

24. Marto, A. \& Tan, C. S. (2016). Properties of coal bottom ash from power plants in Malaysia and its suitability as geotechnical engineering material. Jurn. Teknol., 78(8), 1-10, https://doi.org/10.11113/jt.v78.9603.

25. Kusmiyati et al. (2017). Coal bottom ash and activated carbon for removal of vertigo blue dye in batik textile waste water: Adsorbent characteristic, isotherms, and kinetics studies. Wal. J. Sci. Tech., 14(5), 427-439.

26. Smelcerovic, M. et al. (2015). Low cost removal of direct dye from aqueous solution using waste ashes. Work. Liv. Env. Prot., 12(3), 301-310.

27. Jarusiripot, C. (2014). Removal of reactive dye by adsorption over chemical pretreatment coal based bottom ash. Proced. Chem., 9, 121-130, https://doi. org/10.1016/j.proche.2014.05.015.

28. Mittal, J. et al. (2013). Utilization of bottom ash as a low-cost sorbent for the removal and recovery of a toxic halogen containing dye eosin yellow. Desalin. Water Treat., 52(22), 1-12, https://doi.org/10.1080/19443994.2013.803265.

29. Gorme, J. B. et al. (2010). Characterization of bottom ash as an adsorbent of lead from aqueous solutions. Environ. Eng. Res., 15(4), 207-213, https://doi. org/10.4491/eer.2010.15.4.207.

30. Budi, E. et al. (2016). Activated coconut shell charcoal carbon using chemicalphysical activation. Paper presented at the 2nd Padjadjaran International Physics Symposium, 1-5.

31. Kenneth, N. E., Gounaris, V. \& Hou, W. S. (1992). Adsorption technology for air and water pollution control. Chelsea: Lewis.

32. Mohammed, R. R. \& Chong, M. F. (2014). Treatment and decolorization of biologically treated palm oil mill effluent (POME) using banana peel as novel biosorbent. J. Environ. Manage., 132, 237-249, https://doi.org/10.1016/j. jenvman.2013.11.031.

33. Jayaranjan, M. L. D., Hullebusch, E. D. V. \& Annachhatre, A. P. (2014). Reuse options for coal fired power plant bottom ash and fly ash. Rev. Environ. Sci. Biotechnol., 13(4), 467-486, https://doi.org/10.1007/s11157-014-9336-4. 
34. Sun, W. L. et al. (2008). Adsorption of organic pollutants from coking and papermaking wastewaters by bottom ash. J. Hazard. Mater., 154, 595-601, https://doi.org/10.1016/j.jhazmat.2007.10.063.

35. Noronha, Z. M., Monteiro, J. L. F. \& Gelin, P. (1995). Zeolites: A refined tool for designing catalytic sites. Amsterdam: Elsevier.

36. Karge, H. G. \& Weitkamp, J. (2004). Characterization I. Berlin: Springer Science \& Business Media.

37. Pasbakhsh, P. \& Churchman, G. J. (2015). Natural mineral nanotubes: Properties and applications. Toronto: Apple Academic Press.

38. Song, J. et al. (2011). Adsorption characteristics of methylene blue by peanut husk in batch and column modes. Desalin., 265(1), 119-125, https://doi.org/10.1016/j. desal.2010.07.041.

39. Lin, J. X. et al. (2007). The adsorption of dyes from aqueous solution using diatomite. J. Por. Mater., 14(4), 449-455, https://doi.org/10.1007/s10934-0069039-5.

40. Banerjee, S. \& Chattopadhyaya, M. C. (2017). Adsorption characteristics for the removal of a toxic dye, tartrazine from aqueous solutions by a low cost agricultural by-product. Arab. J. Chem., 10(2), 1629-1638, https://doi.org/10.1016/j. arabjc.2013.06.005.

41. Sia, Y. Y., Tan, I. A. W. \& Abdullah, M. O. (2017). Adsorption of colour, TSS and COD from palm oil mill effluent (POME) using acid-washed coconut shell activated carbon: Kinetic and mechanism studies. MATEC Web Conf., 87, 1-7, https://doi.org/10.1051/matecconf/20178703010.

42. Gao, J. et al. (2013). Production of mesoporous activated carbon from tea fruit peel residues and its evaluation of methylene blue removal from aqueous solutions. BioResour., 8(2), 2145-2160, https://doi.org/10.15376/biores.8.2.2145-2160. 